\title{
MODEL PENINGKATAN KESUKSESAN KARIR OBYEKTIF DAN SUBYEKTIF PADA DOSEN PTIS (PERGURUAN TINGGI ISLAM SWASTA)
}

\author{
Agus Abdullah \\ Universitas Islam Sultan Agung Semarang \\ agus.abdullah@std.unissula.ac.id
}

\begin{abstract}
The purpose of this research is to improve the objective and subjective career success lecturer at PTIS (private Islamic universities) by stimulating the emotional intelligence, intrinsic motivation and competence. The population in this study consisted of three Islamic universities in Semarang, namely: Sultan Agung Islamic University (UNISSULA), University of Wahid Hasyim (UNWAHAS) and the University of Muhammadiyah Semarang (UNIMUS). Total questionnaires distributed to as many as 69 respondents supported by SPSS version 20 as data processor and tools of statistical processing. This study analyzed by linear regression and regression moderation. The variables used are: independent variables such as emotional intelligence and intrinsic motivation, moderation variable such as competence and the dependent variable in the form of objective and subjective career success. The results showed that there is a positive and significant effect of emotional intelligence on objective and subjective career success and competence able to moderate the relationship between intrinsic motivation and career success subjective.
\end{abstract}

Keywords: Emotional Intelligence, Intrinsic Motivation, Objective Career Success, Subjective Career Success.

\section{PENDAHULUAN}

Latar Belakang Masalah

Setiap perusahaan dituntut agar mampu memberikan perencanaan karir untuk setiap karyawannya. Karena karyawan adalah asset yang sangat berharga dan mereka tentu ingin mencapai karir yang bagus didalam pekerjaannya. Karir merupakan pekerjaan atau jabatan yang pernah ditangani atau diduduki selama masa kerja seseorang (Handoko, 200). Senada dengan pernyataan Hani, Mathis dan Jackson (2000) menegaskan bahwa karir adalah urutan posisi yang terkait dengan jabatan pekerjaan yang pernah diduduki seseorang selama hidupnya. Dari dua pernyataan diatas dapat disimpulkan bahwa karir merupakan suatu hal yang sangat berharga dalam kehidupan seseorang.

Heslim (2000) menyatakan bahwa alasan pentingnya karir bagi setiap orang adalah karena berhubungan dengan dua aspek sekaligus, yaitu aspek finansial dan psikologis. Secara finansial karir yang cemerlang akan memberikan individu pendapatan lebih besar dibanding individu lain yang memiliki karir kurang bagus. Kemudian dari sisi psikologis akan membuat individu yang mencapai posisi karir tertentu akan merasa bangga, puas dan bahagia terhadap pencapaiannya tersebut.

Kedua aspek diatas sangatlah erat kaitannya dalam penentuan kesuksesan karir seorang individu. Ada standar umum yang biasanya dijadikan acuan dalam menilai karir seseorang dalam pekerjaannya. 
Namun, setiap individu secara subyektif juga punya ukuran kesuksesannya masingmasing yang itu tidak bisa diukur oleh standar umum seperti tingkat gaji, jabatan atau kehormatan didalam pekerjaannya. Gratiker dan Larwood (1998) memandang bahwa subyektifitas terhadap kesuksesan karir hanyalah sebuah konstruk yang hanya ada dalam diri masing-masing orang dan tidak memiliki batasan-batasan tertentu. Namun Pool, dkk (1930) memandang bahwa kesuksesan karir secara obyektif maupun subyektif berhubungan saling timbal balik dan terkait. Karena kedua hal tersebut dipengaruhi oleh kultur dan struktur sosial yang ada, pengalaman peranan keluarga dan peluang serta hambatan yang dirasakan dalam suatu organisasi.

Pada hakikatnya setiap individu bebas menentukan karirdan ukuran kesuksesannya masing-masing. Namun karena persaingan dalam dunia pekerjaan yang ketat menuntut setiap individu mampu untuk kreatif dalam mengembangkan potensi diri yang dimiliki serta selektif dalam melakukan perencanaan karirnya. Sehingga ada beberapa aspek yang harus dimiliki dalam menunjang pencapaian kesuksesan karir dalam suatu pekerjaan. Diantara banyaknya aspek yang harus dipenuhi itu antara lain adalah kepemilikan kecerdasan emosional, motivasi intrinsik serta kompetensi yang sesuai dengan gambaran pekerjaan.

Menurut Goleman (2003) kecerdasan emosional sangatlah penting dalam dunia kerja, karena didalam kecerdasan emosional terdiri beberapa aspek antara lain: pengendalian rasa sedih, marah, takut dan gembira. Beberapa aspek ini sangatlah penting untuk menunjang sesorang agar sukses dalam setiap pekerjaannya. Namun tidak semua individu bisa dengan mudah untuk mengaplikasikan kecerdasan emosional dalam berprilaku. Sehingga diperlukan latihan dan bimbingan sejak kecil, baik bimbingan dalam lingkungan keluarga maupun sekolah formal.

Untuk mencapai kesuksesan karir baik secara obyektif maupun subyektif, ada beberapa aspek lain yang harus dipenuhi. Beberapa aspek tersebut antara lain adalah memeliki dorongan motivasi yang kuat dan adanya kemampuan yang sesuai dengan gambaran pekerjaan. Motivasi sangatlah penting dalam menunjang keberhasilan seseorang dalam pekerjaannya. Terlebih motivasi tersebut lahir dari dalam diri individu sendiri. Karena dengan lahirnya hal tersebut, seseorang akan semakin menyadari apa yang dilakukan memiliki manfaat baginya kelak, sehingga lebih semangat dan giat dalam menyelesaikannya pekejaannya dengan baik.

Secara umum Hoy dan Miskel (2005) mengemukakan bahwa motivasi merupakan kekuatan-kekuatan yang kompleks, dorongan, kebutuhan, ketegangan (tension states) atau mekanisme-mekanisme yang memulai dan menjaga kegiatan-kegiatan kearah pencapaian diri secara personal. Kemudian menurut Djamarah (2002) motivasi terbagi menjadi 2 (dua) jenis yaitu: motivasi intrinsik dan motivasi ekstrinsik. Namun motivasi intrinsik lebih memiliki keunggulan dibanding motivasi ekstrinsik. Karena motivasi yang datangnya dari dalam diri secara pribadi akan memiliki kekuatan lebih dibanding motivasi yang datangnya dari luar.

Selain itu, motivasi yang tinggi dalam pekerjaan tentu tidak berarti apa-apa tanpa adanya kompetensi yang dibutuhkan. Sehingga aspek kompetensi juga sangatlah berkontribusi dalam menunjang seseorang mencapai kesuksesannya di dunia kerja. Simanjuntak (2005) mengungkapkan bahwa kompetensi dapat memperdalam dan memperluas kesempatan kerja, sehingga mempercepat pencapaian kesuksesan karir. Semakin sering seseorang melakukan pekerjaan yang sama, semakin ahli dan cepat pula seseorang menyelesaikan pekerjaannya. Lebih lanjut lagi, Pramudyo (2010) menjelaskan bahwa kompetensi meliputi beberapa unsur yaitu : pengetahuan (knowledge), keahlian (skill) dan prilaku 
(attitude). Ketiga unsur ini merupakan penentu baik atau buruknya kinerja seseorang dalam pekerjaannya.

Kesuksesan karir baik obyektif dan subyektif adalah suatu hal yang sangat dibutuhkan oleh setiap individu. Karena dengan pencapaiaan tersebut berarti mereka bisa dikatakan berhasil didalam pekerjaannya. Sehingga tercipta kepuasan pribadi dan penilaian baik dari orang lain terkait pencapaian kesuksesan karirnya. Begitupun dalam penelitian ini yang menjadikan para dosen di PTIS Semarang (perguruan tinggi Islam swasta) sebagai objek penelitiannya. Tingkat kesuksesan karir yang mereka capai baik obyektif maupun subyektif sangatlah berpengaruh signifikan terhadap baik atau buruknya pola pikir dan prilaku dari mahasiswa yang mereka ajar. Mahasiswa adalah generasi muda yang kiprahnya sangat diharapkan untuk membawa bangsa ini kearah yang lebih maju. Karena lewat merekalah jati diri bangsa ini dipertaruhkan (Andhayakya, 2008). Namun melihat kondisi generasi muda hari ini yang mengalami degradasi moral, cita-cita tersebut sepertinya susah untuk tercipta. Sehingga banyak yang berkesimpulan pendidikan sebagai sebab dari bobroknya moral anak bangsa.

Bicara tentang pendidikan dan kaitannya dalam memperbaiki moral anak bangsa tentu tidak bisa kita lepaskan dari peran instansi/ lembaga pendidikan yang menggunakan konsep dan metode Islam seperti PTIN/S (Perguruan Tinggi Islam Negeri/Swasta). Namun konsep dan metode saja tidaklah cukup dalam mewujudkan semua itu, tapi juga dibutuhkan seorang dosen yang secara tepat dan sukses dalam mengaplikasikan konsep dan metode tersebut. Untuk mencapai kesuksesan karir baik obyektif atau subyektif dari para dosen seabagi seorang pengajar dibutuhkan beberapa elemen pendukung, diantaranya adalah memiliki kecerdasan emosional yang baik, motivasi intrinsik yang tingi serta kompetensi yang memadai.
Berdasarkan uraian dan penjabaran diatas, artikel ini bertujuan untuk menelaah stimulasi kecerdasan emosional, motivasi intrinsik dan kompetensi menuju peningkatan pencapaian kesuksesan karir obyektif dan subyektif pada para dosen di PTIS Semarang. Objek dalam penelitian ini adalah 3 universitas Islam di Semarang yaitu: Universitas Islam SultanAgung (UNISSULA), Universitas Wahid Hasyim (UNWAHAS) dan Universitas Muhammadiyah Semarang (UNIMUS) dengan para dosen tetap sebagai respondennya. Dosen tetap dipilih sebagai responden karena mereka sudah punya jenjang karir yang bagus. Sehingga sangat cocok untuk mengurai informasi dari mereka terkait data yang dibutuhkan dalam penelitian yang kami lakukan.

\section{KAJIAN PUSTAKA DAN PENGEMBANGAN HIPOTESIS Kecerdasan Emosional}

Chaplin (1975) menguraikan kecerdasan emosional sebagai kemampuan menghadapi dan menyesuaikan diri terhadap situasi baru secara cepat dan efektif. Sementara itu Woolfolk (1975) mengemukan bahwa menurut teori lama, kecerdasan meliputi tiga pengertian, yaitu: kemampuan untuk belajar, keseluruhan pengetahuan yang diperoleh dan kemampuan untuk beradaptasi dengan situasi yang baru atau lingkungan pada umumnya.

Selanjutnya, menurut Howes dan Herald (1999) kecerdasaan emosional merupakan komponen yang membuat seseorang menjadi pintar menggunakan emosi. Lebih lanjut dikatakannya bahwa emosi manusia berada diwilayah dari perasaan lubuk hati dan naluri yang tersembunyi sementara kecerdasaan emosional menyediakan pemahaman yang lebih mendalam dan lebih utuh tentang diri sendiri dan orang lain. Sebelumnya Cooper dan Sawaf (1998) juga mengemukakan pendapatnya tentang kecerdasan emosional. Kecerdasan emosional adalah kemampuan merasakan, memahami dan secara selektif menerapkan 
daya dan kepekaan emosi sebagai sumber energi dan pengaruh yang manusiawi. Kecerdasan emosi menuntut pemerhatian perasaan, untuk belajar mengakui, menghargai perasaan pada diri dan orang lain, menanggapinya dengan tepat serta menerapkan secara efektif energi emosi dalam kehidupan sehari hari.

Goleman (1995) dalam Tjahjoanggoro (2003) mengatakan kecerdasan emosional adalah kemampuan lebih yang dimiliki seseorang dalam memotivasi diri, ketahanan dalam meghadapi kegagalan, mengendalikan emosi, menunda kepuasan serta mengatur keadaan jiwa. Dengan kecerdasan emosional tersebut seseorang dapat menempatkan emosinya pada porsi yang tepat dan secara bijak mengatur suasana hati. Kemudian Solvey dan Mayer (1993) dalam Tjahjoanggoro (2003), mengartikan kecerdasan emosional sebagai himpunan bagian dari kecerdasan sosial yang melibatkan kemampuan memantau perasaan dan emosi baik dari diri sendiri dan orang lain, memilah-milah dan menggunakan informasi ini untuk membimbing pikiran dan tindakan. Selain itu ada beberapa indikator lain menurut Goleman (2006) antara lain: mengenali emosi diri, mengelola emosi, memotivasi diri sendiri, mengenalai emosi orang lain (empati) dan membina hubungan.

\section{Motivasi Intrinsik}

Secara umum, motivasi menurut Purwanto (1998) yaitu pendorongan suatu usaha yang disadari untuk memengaruhi tingkah laku seseorang agar tergerak hatinya menuju apa yang ingin dicapai. Handoko (1992) menyimpulkan motivasi sebagai suatu tenaga atau faktor yang ada pada diri manusia yang menimbulkan, mengarakan dan mengorganisasikan tingkah lakunya. Djamarah (2002) membagi motivasi menjadi 2 bagian, yaitu motivasi intrinsik dan motivasi ekstrinsik. Pada penelitian ini kami lebih akan membahas motivasi intrinsik dalam meningkatkan kesuksesan karir obyektif maupun subyektif seseorang tanpa mengurangi pentingnya motivasi ekstrinsik.

Secara umum motivasi intrinsik adalah motivasi yang mampu mendorong seseorang untuk berprestasi yang lahir dari dalam diri individu tersebut atau kita lebih mengenalnya dengan faktor emosional. Menurut Nawawi (2001), motivasi intrinsik merupakan pendorong kerja yang bersumber dari dalam diri individu berupa keasadaran mengenai penting atau bermanfaatnya pekerjaan yang dilakukan. Hampir senada dengan Nawawi, Sardiman (2007), mengatakan motivasi intrinsik adalah suatu motif-motif yang menjadi aktif atau berfungsinya tidak perlu mendapat rangsangan dari luar, karena dari dalam diri setiap individu sudah ada dorongan untuk melakukan seuatu.

Sedangkan Menurut Gunarsa (2008), motivasi intrinsik merupakan dorongan atau kehendak yang kuat yang berasal dari dalam diri seseorang, semakin seseorang memiliki motivasi intrinsik yang kuat maka akan semakin besar pula ia mampu memperlihatkan tingkah laku yang kuat untuk mencapai tujuan yang diinginkan. Dari berbagai pendapat para ahli di atas, kami menggunakan pendapat Sardiman (2007) sebagai definisi operasional variabel, yaitu motivasi intrinsik adalah perubahan energi dalam diri seseorang yang ditandai dengan munculnya "feeling" atau perasaan dan didahului dengan tanggapan terhadap adanya tujuan.

\section{Kompetensi}

Kompetensi merupakan keinginan untuk memberikan dampak pada orang lain dan kemampuan untuk mempengaruhi orang lain melalui strategi mengajak atau membujuk (Rivai dan Sagala, 2009). Menurut Poerwadarminto (1990), kompetensi adalah kekuasaan untuk menentukan atau memutuskan sesuatu hal. Sedangkan menurut pendapat Allen Black, dkk dalam Mulyasa (2003) mengartikan kompetensi sebagai sifat yang dimiliki seseorang agar mampu berkerja dan belajar dengan baik dan tidak hanya metodologi saja. 
Menurut Grote dalam Pramudya (2010), kompetensi dapat berfungsi sebagai alat untuk mengukur kinerja. Artinya siapa yang nantinya berkinerja baik atau buruk itu tergantung dari kompetensi yang dimiliki. Soto dalam Enceng, Listyodono dan Purwaningdyah (2008)sedikitmenambahkan bahwa kompetensi tidak hanya mengandung keterampilan, pengetahuan dan sikap namun yang terpenting adalah penerapan dari keterampilan, pengetahuan dan sikap mereka harus sesuai dengan standar kinerja yang sudah ditetapkan.

Kompetensi yang dimiliki oleh seseorang akan sanggup memperdalam dan memperluas kemampuan kerja. Karena semakin sering seseorang melakukan pekerjaan yang sama, maka akan semakin terampil dan cepat dia dalam menyelesaikan pekerjaanya. Dan semakin banyak macam pekerjaan yang dilakukan oleh seseorang, maka pengalaman kerjanya akan semakin kaya dan sangat memungkinkan mudahnya peningkatan kinerja serta kesuksesan karirnya (Simanjuntak, 2005). Dari berbagai pendapat para ahli di atas, kami menggunakan pendapat Allen Black, dkk dalam Mulyasa (2003) sebagai definisi operasional variabel, yaitu kompetensi adalah sifat yang dimiliki seseorang agar mampu berkerja dan belajar dengan baik dan tidak hanya metodologi saja.

\section{Kesuksesan Karir Obyektif dan Subyektif}

Judge dan Hurst (2008) mengatakan bahwa terdapat dua aspek kesuksesan karir yaitu aspek subyektif (intrinsic career) dan obyetif atau (extrinsic career). Karir yang memuaskan tentu tergantung pada penilaian subyektif individu terhadap perkembangan karirnya. Hal ini berbeda pada kesuksesan karir obyektif yang dapat dilihat dari status atau jabatan yang dipegang individu di tempat kerjanya, banyaknya promosi yang diperoleh, jumlah gaji yang diterima setiap bulannya. Secara obyektif, kesuksesan karir dapat diukur lewat evaluasi yang dianggap umum di masyarakat dan manajerial (Mclamed, 1996). Nabi (1999) menyatakan bahwa pendidikan, tingkat keterlibatan pada pekerjaan dan struktur serta ukuran organisasi akan berpengaruh terhadap kesuksesan karir obyektif.

Berbeda dengan kesuksean karir obyektif, kesuksesan karir subyektif merupakan kesuksesan yang hanya bisa dirasakan langsung oleh seorang individu (internal) dan terlepas dari perspektif dari luar (eksternal). Dimana seorang individu diharapkan mengelola karirnya sendiri dari pada tergantung pada arah organisasi. Greenhaus, dkk (1990), menambahkan bahwa sukses karir subyektif dapat dilihat dari keseluruhan tujuan yang mereka inginkan dalam pekerjaannya.

GrattikerdanLarwood(1988)berpendapat kesuksesan karir subyektif adalah sebuah konstruk yang haya ada dalam pemikiran orang-orang dan tidak mempunyai batasanbatasan. Dari definisi ini seakan Grattiker dan Larwood ingin menegaskan bahwa belum tentu sukses karir menurut kaidahkaidah kemasyarakatan akan selalu sesuai dengan kesuksesan menurut individu.

Penelitian Saeedi, dkk(2012)menyatakan adanya korelasi positif antara kecerdasan emosional dan kesuksesan karir. Dimana kesadaran diri (self awareness) menjadi dimensi kecerdasan emosi yang paling berpengaruh terhadap kesuksesan karir. Kecerdasan emosional lebih berpengaruh pada keberhasilan individu dalam kehidupan (pribadi dan profesional) dari pada kecerdasan kognitif (Stewart, 2008).

Puffer (2011) mengatakan kecerdasan emosional memiliki pengaruh positif terhadap pemikiran karir yang lebih besar terutama terkait bagaimana karyawan memiliki selfefficacy (percaya diri terhadap kemampuan) dalam melakukan pengambilan keputusan, serta pada tingkat yang lebih tinggi yaitu keinginan untuk mengeksplorasi berbagai preferensi karir dan berkomitmen untuk memperoleh pilihan karir yang menarik.

Kecerdasan emosional adalah faktor 
yang bisa membuat sikap, prilaku dan hasil yang lebih positif (Carmel, 2003) yang pada akhirnya sangat menentukan karir seseorang (Cooper, 1997). Menurut Weisinger (1998), kecerdasan emosional merupakan kecerdasan menggunakan emosi. Dimana orang secara sengaja mengelola emosi kemudian menggunakannya untuk membantu membimbing tangkah laku dan berfikir dalam mengarahkan pencapaian hasil yang lebih tinggi. Hasil penelitian Simboh (2005) menyimpulkan bahwa kecerdasan emosional memberikan kontribusi positif dan signifikan terhadap peningkatan prestasi kerja atau kinerja karyawan dalam melaksanakan tugas pokok dan fungsinya. Azwir (2004) menyatakan IQ (Intelligence Quotient) hanya memberikan kontribusi 20 persen saja dalam kesuksesan seseorang di masa depan, selebihnya ditentukan oleh faktor Kecerdasan Emosional dan faktor lainnya.

Beberapa penelitian seperti Chaudhary (2012), Dieleman (2013), Abonam (2011), Shanthakumary (2012) membuktikan bahwa motivasi berpengaruh positif dan signifikan terhadap kinerja. Dalam penelitian yang dilakukan oleh Fathurahman (2013), motivasi berpengaruh terhadap pencapaian karir seseorang dalam pekerjaannya. Motivasi merupakan penggerak individu melakukan suatu perbuatan yang mengarah pada tujuan yang ingin dicapai. Madinatussalamah (2011) mengatakan bahwa segala hal yang berkaitan dengan bentuk pencapaian prestasi akan dihadapi secara maksimal oleh individu jika memiliki dua macam motivasi yang berasal dari dalam diri (intrinsik) dan juga dari luar individu (ekstrinsik).

Menurut hasil penelitain Adibah (2008) hubungan motivasi baik intrinsik maupun ekstrinsik dan fear of success (ketakutan untuk sukses) bersifat negatif, artinya semakin tinggi motivasi seseorang maka semakin rendah fear of success-nya dan semakin rendah motivasi semakin tinggi fear of success. Hasil penelitian Ncube dan Samuel (2014) juga menunjukkan bahwa variabel motivasi intrinsik dan ekstrinsik berdampak signifikan pada tingkat pencapaian karir seorang karyawan.

Berdasarkan uraian diatas, maka disimpulkan hipotesis-hipotesis sebagai berikut:

$\mathrm{H} 1 \mathrm{a}$ : Bila kecerdasan emosional semakin tinggi, maka kesuksesan karir obyektif semakin tinggi.

$\mathrm{H} 2 \mathrm{~b}$ : Bila kecerdasan emosional semakin tinggi, maka kesuksesan karir subyektif semakin tinggi.

$\mathrm{H} 2 \mathrm{a}$ : Semakin tinggi motivasi intrinsik yang dimiliki seseorang, maka akan semakin tinggi pula kesuksesan karir obyektif.

$\mathrm{H} 2 \mathrm{~b}$ : Semakin tinggi motivasi intrinsik yang dimiliki seseorang, maka akan semakin tinggi pula kesuksesan karir subyektif.

\section{Peran Moderasi Kompetensi}

Satria (2013) mengatakan bahwa motivasi kerja merupakan suatu yang sangat penting untuk diperhatikan dalam pengelolaan sumber daya manusia. Ada beberapa faktor yang mempengaruhi motivasi kerja antara lain adalah kompetensi pegawai, variabel kompetensi pegawai sangatlah berpengaruh terhadap motivasi kerja seseorang. Seseorang yang tidak kompeten di bidangnya tentu saja tidak akan memiliki motivasi kerja yang sungguhsungguh, karena tidak mengetahui secara pasti apa yang ingin dikerjakan.

Menurut Thomas (2000), beberapa faktor yang sangat penting dalam meningkatlan motivasi intrinsik adalah pilihan, kompetensi, kemajuan. Sedangkan Muhyi (2010) menyatakan bahwa kesuksesan seorang individu adalah mereka yang memiliki kompetensi. Kompetensi adalah seseorang yang memiliki ilmu pengetahuan, keterampilan dan kualitas individu yang meliputi sikap, motivasi, nilai serta tingkah laku yang diperlukan untuk melaksanakan pekerjaan/kegiatan. 
Dalam penelitiannya, Iversen (2000) menyatakan kompetensi adalah karakteristik yang dapat diukur, yang biasanya relatif stabil dari seseorang yang dapat memprediksi baik buruk pencapaian karirnya kedepan. Sedangkan kompetensi Menurut Mc. Clelland yang dikutip oleh Sedarmayanti (2011) mengemukakan bahwa kompetensi adalah karakteristik mendasar yang dimiliki seseorang yang berpengaruh langsung terhadap kinerja atau hasil yang akan didapatkan. Karena tinggi rendahnya kinerja atau pencapaian seseorang dapat diprediksi dengan adanya kinerja yang baik.

Berdasarkan uraian diatas, maka disimpulkan hipotesis-hipotesis sebagai berikut:

$\mathrm{H} 3 \mathrm{a}$ : Kompetensi memoderasi pengaruh peranan positif motivasi intrinsik terhadap kesuksesan karir obyektif.

$\mathrm{H} 3 \mathrm{~b}$ : Kompetensi memoderasi pengaruh peranan positif motivasi intrinsik terhadap kesuksesan karir subyektif.

Model Empirik Penelitian hipotesis kedua (H1 b), (c) Hubungan motivasi intrinsik terhadap kesuksesan karir obyektif sebagai variabel ketiga $(\mathrm{H} 2$ a), (d) hubungan motivasi intrinsik terhadap kesuksesan karir subyektif sebagai hipotesis keempat ( $\mathrm{H} 2$ b), (e) pengaruh moderasi kompetensi terhadap hubungan antara motivasi intrinsik dan kesuksesan karir obyektif seabagi hipotesis kelima ( $\mathrm{H} 3$ a) dan (f) pengaruh moderasi kompetensi terhadap hubungan antara motivasi intrinsik dan kesuksesan karir subyektif (H3 b).

\section{METODE PENELITIAN}

Penelitian ini merupakan penelitian survey yang dimaksudkan untuk memberikan penjelasan atau disebut Explanatory Research. Penelitian survey merupakan penelitian yang mengambil sampel dari suatu populasi dan menggunakan kuesioner sebagai alat pengumpulan yang pokok. Menurut Masri Singarimbun (1998), penelitian eksplanatori (explanatory research) merupakan penelitian yang menjelaskan atau menyoroti pengaruh antar

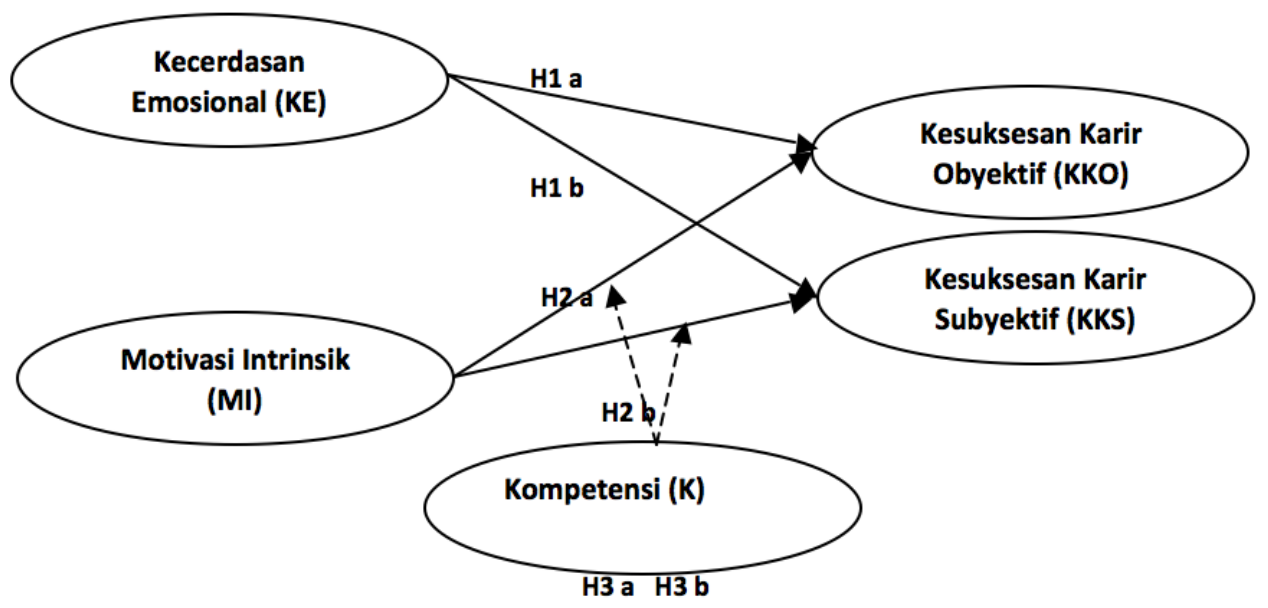

Gambar 1

Model Peningkatan Kesuksesan Karir Obyektif dan Subyektif

Model empirik menggambarkan mengenai hubungan-hubungan antara variabel berikut ini : Hubungan kecedasan emosional terhadap kesuksesan karir obyektif sebagai hipotesis pertama $(\mathrm{H} 1$ a), (b) Hubungan kecerdasan emosional terhadap kesuksesan karir subyektif sebagai variabel penentu serta menguji hipotesis yang telah dirumuskan sebelumnya. Penelitian ini akan dilakukan di 3 universitas swasta Islam di Semarang yang meliputi: Universitas Islam Sultan Agung (UNISSULA) dan Universitas Wahid Hasyim (UNWAHAS) dan Universitas Muhammadiyah Semarang 
(UNIMUS).

Populasi dalam penelitian ini adalah seluruh dosen tetap di 3 universitas swasta islam di Semarang yang meliputi: Universitas Islam Sultan Agung (UNISSULA), Universitas Wahid Hasyim (UNWAHAS), Universitas Muhammadiyah Semarang (UNIMUS) yang berjumlah 680 orang. Metode penarikan sampel dalam penelitian ini menggunakan penarikan
"Purposive Sampling" artinya pengambilan sampel dengan mempertimbangkan karakteristik populasi yaitu: pengalaman kerja minimal 2 tahun sebagai dosen tetap dan merupakan representase dari masingmasing universitas.

\section{Definisi Operasional Variabel dan Indikator}

Hasil rangkuman definisi operasional

Tabel 1

Definisi Operasional Variabel Dan Indikator

\begin{tabular}{|c|c|c|c|c|}
\hline Variabel & Indikator & Rata-rata Nilai & Validitas & Reliabilitas \\
\hline $\begin{array}{l}\text { Kecerdasan Emosional } \\
\text { Himpunan bagian dari } \\
\text { kecerdasan sosial yang } \\
\text { melibatkan kemampuan } \\
\text { memantau perasaan dan } \\
\text { emosi baik dari diri sendiri dan } \\
\text { orang lain, memilah-milah dan } \\
\text { menggunakan informasi untuk } \\
\text { membimbing pikiran dan } \\
\text { tindakan }\end{array}$ & $\begin{array}{ll}\text {. } & \text { Mengenali } \\
\text { emosi diri } \\
\text {. } \\
\text { emgengela } \\
\text { emosi diri } \\
\text {. } & \text { Memotivasi diri } \\
\text { sendiri } \\
\text {. } \\
\text { Mengenali } \\
\text { emosi orang } \\
\text { lain (empati }\end{array}$ & 4,33 & Valid & Reliabel \\
\hline $\begin{array}{l}\text { Motivasi Intrinsik } \\
\text { Suatu motif-motif yang } \\
\text { menjadi aktif atau } \\
\text { berfungsinya tidak perlu } \\
\text { mendapat rangsangan dari } \\
\text { luar, karena dari dalam diri } \\
\text { individu sudah ada dorongan } \\
\text { untuk melakukan sesuatu }\end{array}$ & $\begin{array}{ll}\text {. } & \text { Tanggung } \\
& \text { Jawab } \\
\cdot & \text { Prestasi } \\
\cdot & \text { Pekerjaan } \\
\cdot & \text { Penghargaa } \\
\cdot & \text { Kesempatan } \\
& \text { Berkembang }\end{array}$ & 4,34 & Valid & Reliabel \\
\hline $\begin{array}{l}\text { Kompetensi } \\
\text { sifat yang dimiliki seseorang } \\
\text { agar mampu berkerja dan } \\
\text { belajar dengan baik dan tidak } \\
\text { hanya metodologi saja }\end{array}$ & $\begin{array}{ll}\cdot & \text { Pengetahuan } \\
& \text { (knowledge) } \\
\text { Keterampilan } \\
\text { (skill) } \\
\text { Prilaku (attitude) }\end{array}$ & 4,52 & Valid & Reliabel \\
\hline $\begin{array}{l}\text { Kesuksesan Karir Obyektif } \\
\text { kesuksesan karir yang } \\
\text { bisa diukur lewat evaluasi } \\
\text { yang dianggap umum di } \\
\text { masyarakat dan manajerial }\end{array}$ & $\begin{array}{ll}\cdot & \text { Tingkat gaji } \\
\cdot & \text { Promosi } \\
\cdot & \text { Status atau } \\
& \text { jabatan }\end{array}$ & 3,97 & Valid & Reliabel \\
\hline $\begin{array}{l}\text { Kesuksesan Karir Subyektif } \\
\text { kesuksesan karir yang berupa } \\
\text { konstruk yang hanya ada } \\
\text { dalam pemikirin seorang } \\
\text { individu dan tidak mempunyai } \\
\text { batasan-batasan }\end{array}$ & $\begin{array}{ll}\text {. } & \text { Kemajuan } \\
& \text { dalam karir } \\
\cdot & \text { Prestasi } \\
\cdot & \text { Hasil terhadap } \\
& \text { tujuan dan } \\
\text { aspirasinya }\end{array}$ & 4,28 & Valid & Reliabel \\
\hline
\end{tabular}


variabel dan indikator dapat disajikan dalam Tabel 1.

\section{HASIL DAN PEMBAHASAN}

Hasil pengujian hipotesis dapat disajikan dalam Tabel 2. mempengaruhi kesuksesan karir obyektif maupun subyektif secara signifikan. Hasil ini selaras dengan justifikasi yang digunakan dan sudah dijelaskan pada bab sebelumnya. Penelitian Saeedi, dkk (2012) menyatakan adanya korelasi positif antara kecerdasan

Tabel 2

Ringkasan Hasil Pengujian Hipotesis

\begin{tabular}{|c|c|c|}
\hline Hipotesis & Pernyataan & Hasil Pengujian \\
\hline Hipotesis 1a & $\begin{array}{l}\text { kecerdasan emosional terhadap kesuksesan karir } \\
\text { obyektif }\end{array}$ & Hipotesis Diterima \\
\hline Hipotesis $1 b$ & kecerdasan terhadap kesuksesan karir subyektif & Hipotesis Diterima \\
\hline Hipotesis $2 a$ & motivasi intrinsik terhadap kesuksesan karir obyektif & Hipotesis Ditolak \\
\hline Hipotesis 2b & motivasi intrinsik terhadap kesuksesan karir subyektif & Hipotesis Ditolak \\
\hline Hipotesis $3 a$ & $\begin{array}{l}\text { Kompetensi memoderasi pengaruh peranan positif } \\
\text { motivasi intrinsik terhadap kesuksesan karir obyektif }\end{array}$ & Hipotesis Ditolak \\
\hline Hipotesis 3b & $\begin{array}{l}\text { Kompetensi memoderasi pengaruh peranan positif } \\
\text { motivasi intrinsik terhadap kesuksesan karir subyektif }\end{array}$ & Hipotesis Diterima \\
\hline
\end{tabular}

\section{Pembahasan}

\section{Pengaruh Kecerdasan Emosional} terhadap Kesuksesan Karir Obyektif dan Subyektif

Kecerdasan emosional merupakan komponen dari kecerdasan sosial yang melibatkan kemampuan memantau perasaan dan emosi baik dari diri sendiri dan orang lain, memilah-milah dan menggunakan inforamasi ini untuk membimbing pikiran dan tindakan. Seorang individu tentunya dituntut untuk mampu menyesuaikan diri dengan lingkungan atau instansi dimana dia berkerja. Sehingga akan menciptakan suasana kerja yang nyaman dan menyenangkan.

Berdasarkan analisis yang dilakukan, kecerdasan emosional merupakan salah satu faktor yang mempengaruhi tingginya kesuksesan karir obyektif maupun subyektif. Tingginya kecerdasan emosional akan diikuti dengan peningkatan kesuksesan karir sesorang baik secara obyektif maupun subyektif. Bahkan berdasarkan analisis tersebut kecerdasan emosional emosional dan kesuksesan karir.

Menurut pengamatan kami ketika melakukan penelitian di objek penelitian yaitu: Universitas Islam Sultan Agung, Universitas Wahid Hasyim dan Universitas Muhammadiyah Semarang. Kami mendapatkan informasi bahwa di universitas-universitas tersebut sering kali mengadakan even-even agar semua dosen bisa saling berinteraksi, seperti peringatan hari-hari besar nasional. Antara lain: hari kemerdekaan yang diisi dengan berbagai macam perlombaan, hari kelahiran nabi Muhammad SAW yang diisi dengan pengajian, hari raya Idhul Adha yang diisi dengan acara takbir keliling lingkungan kampus dan beberapa kegiatan yang lain. Bahkan tidak hanya di lingkup universitas saja, namun di masing-masing fakultaspun mereka juga mengadakan kegiatan-kegitan serupa guna menciptakan kekompakan dan rasa persaudaraan diantara para dosen. Sehingga berimbas kepada rasa saling mengerti dan memahami diantara para dosen. Kekompakan dan rasa persaudaraan 
inilah yang akhirnya mampu meningkatkan kecerdasan emosional dosen yang meliputi: mengenali emosi diri, mengelola emosi, memotivasi diri dan mengenali emosi orang lain.

Kemudian kalau paneliti cermati tidak adanya sekat meja kerja para dosen di 3 universitas tersebut juga semakin membuat kekeluargaan diantara mereka terjalin sangat harmonis. Rasa saling memiliki dan kekeluargaan yang tercipta di ruang kerja inilah kiranya yang membuat para dosen untuk selalu semangat dan giat dalam berkerja. Rasa semangat dan senang yang ditunjukan para dosen terhadap pekerjaannya akan sangat berimbas kepada meningkatnya kinerja masingmasing dosen. Karena sebagai pekerja tentu tidak hanya uang dan jabatan yang menjadi tujuan namun juga ada hal-hal lain yang diinginkan seperti: suasana kerja yang menyenangkan, kekeluargaan yang tercipta dan rasa yang saling memahami diantara para dosen. Keseluruhan aspek inilah yang akhirnya mampu membuat para dosen mencapai kesuksesan karir obyektif maupun subyektifnya.

\section{Pengaruh Motivasi Intrinsik terhadap Kesuksesan Karir Obyektif dan Subyektif}

Secara umum motivasi intrinsik
merupakan motivasi yang mampu mendorong seseorang untuk berprestasi yang lahir dari dalam individu tersebut atau kita lebih mengenalnya dengan faktor emosional. Motivasi intrinsik merupakan dorongan atau kehendak kuat yang berasal dari dalam diri sesorang. Sehingga semakin seseorang memiliki motivasi intrinsik yang kuat, maka akan semakin kuat pula ia mampu memperlihatkan tingkah laku untuk mencapai tujun yang diinginkan.

Berdasarkan hasil analisis yang telah dilakukan menunjukan bahwa motivasi intrinsik tidak mempengaruhi kesuksesan karir obyektif seorang dosen secara signifikan. Hasil tersebut, menunjukkan perbedaan terhadap justifikasi yang telah digunakan dan dijelaskan di bab sebelumnya. Menurut hasil penelitian Ncube dan Samuel (2014) menunjukkan bahwa variabel motivasi intrinsik dan ekstrinsik berdampak signifikan pada tingkat pencapaian karir seorang karyawan.

Berdasarkan data yang dijadikan dasar penelitian ini dapat dilihat bahwa hubungan antara meningkatnya motivasi intrinsik dengan kesuksesan karir obyektif dan subyektif bersifat fluktuatif. Artinya ada saat dimana ketika motivasi intrinsik seseorang naik namun tidak berpengaruh apa-apa terhadap kesuksesan karir obyektif dan subyektifnya. Hal semacam ini terjadi karena responden dalam penelitan ini adalah para dosen tetap di universitas islam yaitu: Universitas Islam Sultan Agung, Universitas Wahid Hasyim dan Universitas MuhammadiyahSemarang. Sebagaiseorang dosen, apalagi dengan latar belakang tradisi keislaman yang baik tentu tidak terlalu memikirkan pencapaian kesuksesan karir obyektif seperti: mendapatkan gaji tinggi, promosi serta jabatan yang tinggi dalam pekerjaannnya menjadi seorang pengajar. Karena beberapa dari mereka ada yang cenderung hanya ingin memuaskan keinginan pribadinya yaitu mengamalkan ilmu yang dimiliki. Sehingga mereka lebih mengedepankan kepuasan diri sendiri dibanding mendapat pengakuan orang lain atas kesuksesan yang didapatkan dengan standar-standar kesuksesan karir secara umum. Dari pengamatan peneliti, ini berarti sebagai seorang pengajar yang bekerja di universitas islam yang tentu mereka sangat lekat dengan nilai-nilai keislaman yang tinggi akan cenderung ingin mencapai kepuasan pribadinya atau kesuksesan karir subyektifnya dibandingkan dengan pengakuan orang lain atau pencapaian kesuksesan karir obyektifnya.

Namun dari hasil pengolahan data dalam penelitian ini, didapatkan hasil yang berbeda. Dimana motivasi intrinsik yang dimiliki dosenpun tidak ada pengaruh signifikan terhadap kesuksesan karir subyektifnya. Disini peneliti menduga 
bahwa indikator dalam memberi batasan pengertian motivasi intrinsik yang dipakai peneliti dalam penelitian ini kurang sesuai dengan objek dan responden yang diteliti. Sebagai seorang dosen universitas islam yang tugasnya membagikan ilmu yang dimiliki tentu akan memiliki motivasi intrinsik yang berbeda dengan profesi lainnya seperti pegawai bank atau perusahaan lainnya. Sehingga sangatlah perlu menyesuaikan indikator motivasi intrinsik bagi objek dan responden yang diteliti yaitu: dosen dan universitas-universitas islam.

\section{Peran Moderasi Kompetensi pada Hubungan antara Motivasi Intrinsik kepada Kesuksesan Karir Obyektif dan Subyektif}

Kompetensi merupakan salah satu alat untuk untuk mengukur kinerja seorang pekerja. Artinya baik atau buruknya hasil pekerjaan seseorang, tidak bisa dihindarkan dari kompetensi yang dimiliki. Dengan kompetensi, seseorang dapat memperdalam atau memperluas kemampuan kerja. Karena dengan memiliki beberapa komponen kompetensi seperti: pengetahuan, keterampilan serta prilaku yang baik akan memudahkan dia menyelesaikan tugastugas didalam pekerjaannya. Sehingga akan mempercepat pencapaian karirnya.

Berdasarkan hasil analisis yang telah dilakukan menunjukan bahwa kompetensi tidak mampu memoderasi hubungan antara motivasi intrinsik terhadap kesuksesan karir obyektif. Hasil ini menununjukan perbedaan dengan justifikasi yang telah digunakan dan dijelaskan pada bab sebelumnya. Hal ini sangatlah wajar terjadi karena pertama motivasi intrinsik tidak mampu meningkatkan kesuksesan karir obyetif dosen, dan yang kedua rata-rata dosen tidak menjadikan kesuksesan karir obyektifnya sebagai acuan utama yang ingin diraih. Sehingga dengan setinggi apapun kompetensi yang dimiliki para dosen, tidak akan mampu memoderai hubungan antara motivasi intrinsik terhadap kesuksesan karir obyektif para dosen.

Namun berbeda dengan hasil yang didapatkan dari analisis pengaruh moderasi kompetensi terhadap hubungan antara motivasi intrinsik dan kesuksesan karir subyektif yang memiliki hubungan signifikan. Hal ini justru selaras dengan penelitian yang dilakukan Muhyi (2010) bahwa kompetensi merupakan faktor penting dalam mencapai kesuksesan karir. Sehingga kompetensi mampu memoderasi hubungan diantara motivasi intrinsik dan kesuksesan karir subyektif. Hasil ini membuktikan bahwa ternyata hanya dengan kepemilikan motivasi intrinsik saja tidak akan mampu meningkatkan karir subyektifnya. Sehingga seorang dosen perlu memiliki kompetensi seperti: pengetahuan, keterampilan dan etika yang baik untuk meningkatkan kesuksesan karir subyektifnya.

\section{SIMPULAN}

Kecerdasan emosional memegang perananyang penting bagi baik atau buruknya kinerja dosen dalam menyelesaikan tugastugasnya, maka dapat diambil kesimpulan bahwa ada hubungan yang positif dan signifikan antara kecerdasan emosional dengan kesuksesan karir obyektif dan subyektif yang dicapai oleh para dosen. Meskipun pihak manajemen Universitas Islam Sultan Agung, Universitas Wahid Hasyim dan Universitas Muhammadiyah Semarang sudah menyelenggarakan berbagai kegiatan agar para dosen saling berinteraksi.

Peneliti menyarankan agar jajaran manajerial uneversitas perlu juga menyelenggarakan pelatihan-pelatihan yang dapat lebih meningkatkan kecerdasan emosional dosen seperti misalnya anger management, team building dan lain-lain. Pelatihan-pelatihan semacam itu akan membuat para dosen merasa fresh kembali dan juga melatih para dosen untuk saling mengerti, berkerja sama dan membantu satu sama lain.

Selain kepemilikan kecerdasan emosional, seorang dosen juga harus memiliki beberapa kompetensi antara lain: Mampu merancang pembelajaran 
yang menarik dan mudah dipahami oleh mahasiswa. Mampu mengkondisikan suasana kelas ketika mengajar. Karena dengan mampu menghidupkan suasana kelas, akan membuat para mahasiswanya antusias dalam mengikuti pelajaran. Mampu meningkatkan kemampuan dalam penguasan materi yang diajarkan. Sehingga mereka dituntut agar sering update informasi dari berbagai macam sumber seperti jurnal dan buku.

1) Mampu menampilkan kepribadian atau etika yang baik. Hal itu bisa dilakukan dengan pandai menempatkan diri, adil terhadap para mahasiswa tanpa membedabedakan, bersikap dewasa dan bijaksana dalam memberikan pembelajaran, mengambil keputusan dan menyikapi permasalahan yang ada.

Selain kemampuan yang harus dimiliki oleh seorang dosen dalam menunjang pencapaiankesuksesankarirnya. Universitas bersama jajarannya diharapkan juga agar melakukan evaluasi kinerja dosen dengan mahasiswa sebagai penilainya serta ada tindak lanjutnya seperti pemberian teguran serta diadakannya pelatihan-pelatihan yang disesuaikan dengan kompetensi yang ingin ditingkatkan. Sehingga seorang dosen akan tahu kekurangnnya dan akan selalu berusaha meningkatkan kemampuannya guna mencapai kesuksesan karir baik obyektif maupun subyektifnya.

\section{DAFTAR PUSTAKA}

Chaplin, J.P. (1998). Kamus Lengkap Psikologi. Terj. Kartini Kartono, Jakarta: PT. Grafindo Persada.

Cooper, Robert dan Sawaf. (2002). Executive EQ. Kecerdasan Emosional dalam Kepemimpinan dan Organisasi. Jakarta: PT. Gramedia Pustaka Utama.

Djamarah, S. B. (2008). Motivasi Belajar. Jakarta: PT. Rineka Cipta.

Enceng, L. dan Purwaningdyah. (2008). Meningkatkan Kompetensi Aparatur Pemerintah Dalam Mewujudkan Good Governance. Jurnal Kebijakan dan Manajemen PNS.

Goleman, D. (2003). Emotional Intelligence. Jakarta: PT. Gramedia Pustaka Utama.

Handoko, H. (2010). Manajemen Personalia dan Sumber Daya Manusia, Edisi Kedua. Yogyakarta: BPFE UGM.

Hoy, dan Miskel. (2006). Educational Administration. Jakarta: PT. Rineka Cipta

Mathis. L. R., dan Jackson. John. (2001). Manajemen Sumber Daya Manusia, Jakarta : Buku kedua.

Nabi, G. R. (1999). An Investigation Into The Differential Profile Of Predictors Of Objective And Subjective Career Success. Career development international. 4 (4), 212-224.

Nawawi, H. (2001). Manajemen Sumber Daya Manusia. Jakarta: Gadjah Mada University Press.

Pool, M.E, Langan, F \& Omodei, M. (1993). Contrasting Subjective And Objective Criteria As Determinants Of Perceived Career Success: A Longitudinal Study. Journal of occupational an organizational psychology, 66: 39-54.

Pramudyo, A. (2010). Analisis faktor-faktor yang mempengaruhi kinerja dosen negeri dipekerjakan kopertis wilayah v Yogyakarta. JBTI 1 (1).

Rivai, V. dan Sagala. (2009). Manajemen Sumber Daya Manusia Untuk Perusahaan. Jakarta: Raja Grafindo Persada

Sardiman, A. M. (2007). Interaksi dan Belajar Mengajar. Jakarta: Raja Grafindo Persada

Simanjuntak, Payama. (2005). Manajemen dan Evaluasi Pekerja, Jakarta: FE UII.

Woolfolk, A. E. (1975). Educational Psychology for Teachers. United States of America. New Jersey. 